\title{
Ten colleges combine forces to strengthen Earth Sciences
}

\section{Washington}

TEN small liberal arts colleges which have already had a disproportionate impact on graduate research in the Earth sciences are hoping to improve that record with a $\$ 450,000$ grant from the W.M. Keck Foundation. The grant to the ten-college consortium will permit joint facultystudent research projects as well as shortterm faculty exchanges.

Four-year liberal arts colleges have regularly provided a large number of graduate students to US universities (see Nature $322,203 ; 1986)$. This is borne out by a 1982 survey of 876 undergraduate institutions conducted by Franklin and Marshall College, a member of the ten-college consortium. The survey showed that although the ten colleges now banding together produced less than one per cent of the total number of first degrees in the institutions surveyed, they accounted for more than a quarter of the total graduate degrees in the Earth sciences.

The colleges in the consortium are Amherst (Massachusetts), Beloit (Wisconsin), Carleton (Minnesota), Colorado College, Franklin and Marshall (Pennsylvania), Pomona (California), Smith (Massachusetts), Whitman (Washington), Williams (Massachusetts) and College of Wooster (Ohio).

Reinhard Wobus, a geology professor at Williams College in Williamstown, says the strength of the small colleges comes from the opportunities for close faculty student interactions. The Keck grant will offer top undergraduates in the Earth sciences a chance to participate in professional research. In the spring following each summer's research projects, there will be a conference to discuss the findings.

Wobus says a similar programme sponsored by the National Science Foundation in the early 1970 s involving Williams and three neighbouring colleges proved the value of such experience. If there is a problem with the new programme, Wobus believes it will be logistical. The ten colleges are scattered throughout the United States.

Improving instructional skills is also a goal of the consortium. Faculty from the colleges will go on three-day visits to the other institutions to observe classes and conduct guest lectures.

The first research projects will begin this summer. One, directed by Wobus, will collect and analyse material thrown up by volcanoes in the Thirtynine Mile volcanic field in central Colorado. Other projects this summer will be a study of ancient stream systems in Montana and carbonate sedimentation on San Salvador island in the Bahamas. Although the programme will be limited to three research projects this summer, the number should double in 1988.

Joseph Palca

\section{Tokyo}

JAPANESE National Railways (JNR) established a world record last week when the magnetically levitated (Maglev) train reached a speed of $\mathbf{4 0 0} \mathbf{~ k m}$ an hour with a crew of three abroad. The successful

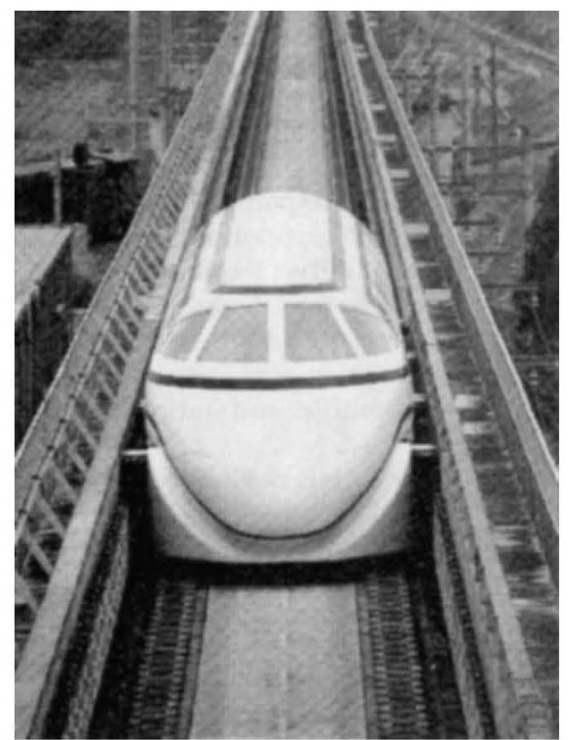

The new high-speed Maglev train. experiment sets the stage for test runs of a prototype commercial vehicle later this year.

The new record was made possible by doubling the electrical capacity of JNR's 7km test track at Miyazaki, Kyushu, to $6,000 \mathrm{~V}$, and shattered the previous record of $350 \mathrm{~km}$ per hour for a manned train set by West Germany's Transrapid 06 vehicle in December 1985.

Japan's MLU-001 experimental train 'floats' on on-board superconducting magnets and is propelled forward by magnetic coils set in the sides of the trackway. A prototype commercial vehicle capable of carrying 44 passengers at a speed of up to $420 \mathrm{~km}$ an hour will begin tests in March on the Miyazaki test track, and Yoshihiro Kyotani, manger of the Maglev project, hopes that a new 50-km trackway for the prototype will be constructed by the end of this decade. Seven prefectures, including Hokkaido, Yamanashi and Saitama, have already expressed interest in the new line which will cost at least $Y 150,000$ million ( $\$ 1,000$ million) to build and can be put into commercial use once experiments are completed.

\section{Japan under fire from US on supercomputers}

\section{Washington}

SUPERCOMPUTERS are the latest Japanese products to come under scrutiny by the Office of the US Trade Representative, this time at the behest of the White House. The results of an investigation begun last year will be disclosed next month.

The President's Trade Strike Force, an informal body at cabinet level, asked for the Trade Representative's investigation, apparently in response to the first purchase of a Japanese supercomputer by a US corporation. The Houston Area Research Center (HARC) - a non-profit corporation designed to link government and industry with the research capabilities of local universities - announced last year that it was acquiring a Nippon Electronics Corporation (NEC) SX2 supercomputer for $\$ 20$ million. The prospect of Japan successfully invading another market hitherto dominated by indigenous companies evidently provoked the request for an investigation.

The investigation is being carried out in parallel with the Market Oriented Sector Selective (MOSS) talks with Japan, which deal with the Japanese markets from which the United States has been excluded. These include pharmaceuticals, electronics, lumber, automobile parts and telecommunications equipment. Supercomputers have now been added to the electronics segment of the talks which apparently are going 'slowly'.

Two US companies now manufacture supercomputers; Cray Research Inc. and Control Data Corporation (CDC). Cray has sold six supercomputers in Japan, the latest of them last month, when Honda bought a $\$ 5.5$ million Cray X-MP/1. The $\mathrm{X}-\mathrm{MP} / 1$ has only a quarter of the power of its big cousin, the X-MP/4, but is still 50 per cent more powerful than the Cray 1. So far, CDC has not sold any supercomputers in Japan.

Bob Gaertner, vice president for communications for Cray Research, says Cray's problems in Japan have been chiefly in sales to government agencies and universities. Cray's Japanese sales total $\$ 60$ million, all to the private sector. Gaertner says Cray wants to expand Japanese sales and is "anxious to have a more open market". So far, Cray has sold 24 of its top-of-the-line supercomputers worldwide; $18 \mathrm{X}-\mathrm{MP} / 4 \mathrm{~s}$ and six Cray $2 \mathrm{~s}$.

HARC's SX2 can perform 1,300 million floating point operations per second (1.3 gigaflops). The new CDC ETA/10 operates at only 10 gigaflops, and costs between $\$ 15$ and $\$ 21$ million depending on how it is supplied. 